\title{
PENERAPAN TEORI ERGONOMI PADA PELATIHAN SERVICE KENDARAAN BERMOTOR RODA DUA UNTUK MENCIPTAKAN KONDISI KERJA EFEKTIF EFISIEN AMAN DAN NYAMAN DI DESA SRIKMULYAN
}

\author{
${ }^{1}$ Ade Suhara, ${ }^{2}$ Ahmad Ridho Nurohman \\ Adesuhara@ubpkarawang.ac.id; ti17.ahmadnurohman@mhs.ubpkarawang.ac.id
}

\begin{abstract}
Abstrak :
Dalam dunia kerja kondisi kerja yang ENAASE (efekfif, nyaman, dan efisien) sangat berperan atau mempengaruhi bagi pekerja dan perusahaan agar dapat memperoleh hasil kerja atau produksi yang maksimal dengan kata lain kondisi kerja yang enase sangat menentukan dalam memperoleh profit/keuntungan perushaan tersebut. Kondisi kerja yang ENASE adalah Suatu pekerjaan akan terlaksana dengan baik apabila pekerjaan itu dilaksanakan dengan ENASE sehingga untuk menghasilkan sebuah pekerjaan dengan optimal maka diperlukan sebuah perancangan sistem kerja yang bersifat ENASE. Selain itu juga perancangan kerja yang ENASE bisa membuat pekerjaan yang sukar menjadi sebuah pekerjaan yang mudah dilaksanakan karena telah memiliki sebuah perencanaan yang baik. Maksud dari perancangan sistem kerja yang ENASE adalah diharapkan sistem kerja yang dirancang efektif yakni mampu menghasilkan output sesuai dengan tujuan yang ditetapkan, nyaman, aman, dan sehat bagi pekerja dan orang-orang yang berada di sekitar lingkungan tempat kerja itu berlangsung, serta efisien dalam arti bahwa biaya yang diperlukan untuk menyelesaikan suatu pekerjaan tertentu kecil nilainya dibanding dengan output yang dihasilkan. Maka dari itu untuk memperoleh hasil produksi yang maksimal dan profit/keuntungan yang maksimal maka perushaan tersebut harus menerapkan kondisi yang enase(efektif, nyaman, dan efisien) agar para karyawan/pekerja dari perusahaan tersebut merasa nyaman dalam bekerja.
\end{abstract}

Kata kunci: enase, tempat kerja, karyawan/pekerja

\section{PENDAHULUAN}

Usaha Mikro Kecil dan Menengah (UMKM) dianggap sebagai cara yang efektif dalam pengentasan kemiskinan. UMKM juga mampu memperluas lapangan kerja, memberikan pelayanan ekonomi secara luas kepada masyarakat. UMKM telah diatur secara hukum melalui Undang-undang Nomor 20 Tahun 2008 tentang Usaha Mikro, Kecil dan Menengah. UMKM merupakan kelompok pelaku ekonomi terbesar dalam perekonomian Indonesia dan terbukti menjadi katup pengaman perekonomian nasional dalam masa krisis, serta menjadi dinamisator pertumbuhan ekonomi pascakrisis ekonomi. "Menurut Kementerian Koperasi dan UKM, sumbangan UMKM terhadap PDB Indonesia mencapai angka 60,34 persen pada tahun 2017, artinya sekitar 60 persen nilai barang dan jasa yang diproduksi di Indonesia pada tahun tersebut berasal dari UMKM. UMKM juga menciptakan peluang kerja yang cukup besar bagi tenaga kerja dalam negeri, sehingga sangat membantu upaya mengurangi pengangguran.

Selain itu, masyarakat juga perlu mengetahui mengenai kekuatan dan kelemahan UMKM berdasarkan hal tersebut Teknik Industri Universitas Buana Perjuangan Karawang, pada 30 November 2019 di Desa Srikamulyan, Kecamatan Tirtajaya, Kabupaten Karawang melaksanakan pengabdian masyarakat. Kegiatan ini diharapkan dapat memotivasi warga desa untuk membuka peluang bisnis UMKM secara mandiri melalui dunia otomotif atau bengkel kendaraan bermotor roda dua.

Dengan memberikan edukasi kondisi kerja yang baik selain itu juga perancangan kerja yang ENASE (Efektif, Nyaman, Aman, Sehat, dan Efisien) bisa membuat pekerjaan yang sukar menjadi sebuah pekerjaan yang mudah dilaksanakan karena telah memiliki sebuah perencanaan yang baik. Maksud dari perancangan sistem kerja yang ENASE adalah diharapkan sistem kerja yang dirancang efektif yakni mampu menghasilkan output sesuai dengan tujuan yang ditetapkan, nyaman, aman, dan sehat bagi pekerja dan orang-orang yang berada di sekitar lingkungan tempat 
kerja itu berlangsung, serta efisien dalam arti bahwa biaya yang diperlukan untuk menyelesaikan suatu pekerjaan tertentu kecil nilainya dibanding dengan output yang dihasilkan.

Perancanaan kondisi kerja ini dilaksanakan bersamaan dengan perencanaan layout tempat kerja tersebut, maka dari itu kondisi kerja ini berhubungan dengan layout yang didirikan perushaan tersebut. Banyak faktor yang mempengaruhi kondisi kerja enase penerangan, suhu udara, suara bising, penggunaan warna, ruang gerak yang diperlukan serta keamanan kerja dalam perusahaan. Masing-masing jenis kondisi kerja ini perlu dipersiapkan dan direncanakan dengan baik oleh manajemen perusahaan tersebut, sehingga diperoleh kondisi kerja yang ENASE (Efektif, Nyaman, Aman, Sehat, dan Efisien) bagi para karyawan yang bekerja di perusahaan tersebut dalam melakukan produksi.

\section{Pengertian kondisi kerja menurut kerja para ahli:}

Menurut Stewart and Stewart(1983: 53)," Working condition can be defined as series of conditions of the working environment in which become the working place of the employee who works there". yang kurang lebih dapat diartikan kondisi kerja adalah serangkaian kondisi atau keadaan lingkungan kerja dari suatu perusahaan yang menjadi tempat bekerja dari para karyawan yang bekerja didalam lingkungan tersebut. Yang dimaksud adalah kondisi kerja yang baik yaitu nyaman dan mendukung pekerja untuk dapat menjalankan aktivitasnya kerjanya dengan baik dan maksimal. Meliputi segala sesuatu yang ada di lingkungan karyawan yang dapat mempengaruhi kinerja, serta keselamatan dan keamanan kerja, temperatur, kelambapan, ventilasi, penerangan, kebersihan, gerakan, kebisingan, faktor ruangan tempat kerja dan lain-lain.

Menurut Newstrom (1996:469), "Work condition relates to the scheduling of work-the length of work days and the time of day (or night) during which people work". yang kurang lebih berarti bahwa kondisi kerja berhubungan dengan penjadwalan dari pekerjaan, lamanya bekerja dalam hari dan dalam waktu sehari atau malam selama orang-orang bekerja.

Maka sebab itu kondisi kerja yang terdiri dari faktor-faktor seperti kondisi fisik, kondisi psikologis, dan kondisi sementara dari lingkungan kerja, harus diperhatikan agar para pekerja dapat merasa nyaman dalam bekerja sehingga dapat meningkatkan produktivitas kerja dan keuntungan bagi perusahaan tersebut.Berikut ini adalah faktor-faktor yang mempengaruhi kondisi kerja:

\section{Kondisi Fisik dari lingkungan kerja}

Menurut Handoko (1995:84)," lingkungan kerja fisik adalah semua keadaan yang terdapat di sekitar tempat kerja, yang meliputi temperatur, kelembaban udara, sirkulasi udara, pencahayaan, kebisingan, getaran mekanis, bau-bauan, warna dan lain-lain yang dalam hal ini berpengaruh terhadap hasil kerja manusia tersebut".

\section{A. Illumination(Penerangan)}

Menurut Newstrom (1996:469-478), "cahaya atau penerangan sangat besar manfaatnya bagi para karyawan guna mendapat keselamatan dan kelancaran kerja”. Pada dasarnya, cahaya dapat dibedakan menjadi dua bagian, yaitu: cahaya yang berasal dari sinar matahari dan cahaya buatan seperti lampu. Oleh sebab itu perlu diperhatikan adanya penerangan (cahaya) yang terang tetapi tidak menyilaukan pekerja atau karyawan. Dengan penerangan yang baik para karyawan akan dapat bekerja dengan cermat dan teliti sehingga hasil kerjanya mempunyai kualitas yang memuaskan. Cahaya yang kurang jelas (kurang cukup) mengakibatkan penglihatan kurang jelas, sehingga pekerjaan menjadi lambat, banyak mengalami kesalahan, dan pada akhirnya menyebabkan kurang efisien dalam melaksakan pekerjaan, sehingga tujuan maupun hasil produksi dari perusahaan terhambat.

Penerangan dalam kondisi kerja adalah cukupnya sinar atau cahaya yang masuk di dalam ruang kerja masing-masing karyawan perusahaan dalam melakukan kerja. Penerangan untuk ruang kerja merupakan faktor yang sangat penting dalam halnya dengan peningkatan produktivitas kerja dari perusahaan, sehingga para karyawan akan terdorong untuk bekerja 
dengan lebih baik dan hasil kerja yang diperoleh perusahaan akan menjadi lebih baik. Penerangan yang tidak memadai akan mengakibatkan para karyawan tidak jelas dalam melakukan pekerjaan seperti melihat obyek dan mengamati pekerjaan yang dilakukan, dimana hal tersebut akan memperbesar tingkat kesalahan kerja dari para karyawan dan akan merugikan perusahaan tersebut. Tepat tidaknya obyek yang dilihat oleh para karyawan juga akan dipengaruhi oleh penerangan atau tata cahaya ditempat kerja ini. Sehingga semakin jelas bahwa penerangan yang memadai pada tempat kerja karyawan akan sangat membantu karyawan dalam usaha peningkatan produktivitas kerja karyawan dan meningkatkan kualitas kerja, perbaikan kualitas kerja dan hasil kerja, peningkatan keamanan kerja dalam proses produksi serta keberhasilan pelaksanaan proses produksi dalam perusahaan.

Tingkat cahaya ini tentunya harus cukup terang dan memadai sehingga tidak menimbulkan ketegangan pada mata karyawan. Jalur yang digunakan untuk pejalan kaki haruslah juga memadai dari segi pencahayaan. Harus dicegah adanaya cahaya yang terpusat yang dapat menyilaukan karyawan, jika perlu gunakan tirai untuk mencegah kesilauan tersebut.

Adapun beberapa keuntungan yang akan dapat diperoleh dengan pelaksanaan sistem penerangan yang tepat di tempat kerjaa karyawan bagi perusahaan, antara lain sebagai berikut:

a. Kenaikan hasil produksi.

b. Meningkatnya kualitas pekerjaan para karyawan

c. Tingkat kecelakaan yang terjadi dapat berkurang

d. Kemudahan pengamatan dan pengawasan

e. Peningkatan gairah kerja para karyawan

f. Perputaran karyawan akan berkurang

g. Kerusakan barang dalam proses berkurang

h. Biaya produksi dapat ditekan

\section{B. Temperature(Suhu)}

Menurut Newstrom (1996:469-478), "bekerja pada suhu yang panas atau dingin dapat menimbulkan penurunan kinerja". Secara umum, kondisi yang panas dan lembab cenderung meningkatkan penggunaan tenaga fisik yang lebih berat, sehingga pekerja akan merasa sangat letih dan kinerjanya akan menurun, sedangkan kondisi dingin dapat menyebabkan para karyawan mengigil yang dapat mengakibatkan terhambatnya produksi dari perusahaan tersebut.

Suhu udara ruang kerja para karyawan perusahaan akan ikut mempengaruhi produktivitas kerja para karyawan. Suhu yang terlalu panas bagi para karyawan perusahaan ini akan dapat menjadi penyebab turunnya gairah kerja para karyawan tersebut.Kondisi suhu rungan haruslah memadai bagi pekerja. Suhu yang terlalu panas dan terlalu dingin tentu menyebankan pekerja kurang merasa nyaman. Saat ini banyak sekali jam dinding yang sudah terintegrasi dengan alat pengukur suhu dan kelembapan ruangan. Hal ini tentu bisa kita manfaatkan sebagai pengganti jam dinding yang biasa kita gunakan. Beberapa jalan yang dapat digunakan oleh manajemen perusahaan di dalam rangka pengaturan suhu udara dalam ruang kerja para karyawan dari perusahaan yang bersangkutan tersebut anatara lain:

a. $\quad$ Ventilasi yang cukup pada tempt kerja

Apabila tempat kerja dilengkapi dengan ventilasi udara yang cukup, maka pertukaran udara yang memadai akan dapat diharapan terjadi pada masing-masing ruang kerja para karyawan, sehingga dapat melaksanakan tugas dengan baik. Biaya untuk pemasangan ventilasi relatif murah dan hanya dikeluarkan pada saat pembangunan. Kandungan udara yang segar haruslah mencukupi dan terbebas dari segala pencemaran termasuk debu ataupun uap. Adanaya jendela yang dapat dibuka dan ditutup juga harus diperhatikan. Menerapkan aturan dilarang merokok di lingkungan kerja sangatlah disarankan karena hal ini tidak hanya berbahaya dari segi perokoknya saja tetapi juga berbahaya untuk perokok pasif atau untuk menghindari bahaya pada perokok pasif tersebut buatlah suatu ruangan khusus untuk merokok. 
Jika di dalam ruangan menggunakan suatu AC maka perhatikan juga tidak ada arus udara dari outlet, memeriksa keberadaan bakteri legionella serta tingkat kebisingan dari AC itu sendiri.

\section{b. Pemasangan kipas angin}

Untuk membantu proses terjadinya pertukaran udara yang cukup di dalam ruang kerja, maka umumnya kipas angin terpasang dalam ruang kerja. Biaya untuk pemasangannya relatif kecil namun memerlukan biaya operasional.

\section{c. Pemasangan air conditioning}

AC dapat digunakan untuk pengaturan udara dan kelembapan udara. Biaya pemasangan serta biaya operasional dari alat ini cukup tinggi akan menyebabkan kebanyakan perusahaan kecil dan menengah tidak mempergunakannya. Namun bagi perusahaan besar hal ini mungkin sudah biasa.

\section{d. Pemasangan humidifier}

Peralatan yang lain dapat dipergunakan dalam usaha untuk mengatur suhu udara dan kelembapan ini adalah humidifier. Dengan alat ini maka kelembapan udar di dalam ruang kerja tersebut akan dapat disesuaikan dengan kebutuhan pelaksanaan proses produksi di dalam perusahaan yang bersangkutan.

\section{Noise(Kebisingan)}

Menurut newstrom (1996:469-478)," bising dapat didefinisikan sebagai bunyi yang tidak disukai, suara yang mengganggu atau bunyi yang menjengkelkan suara bising adalah suatu hal yang dihindari oleh siapapun, lebih-lebih dalam melaksanakan suatu pekerjaan, karenakonsentrasi perusahaan akan dapat terganggu". Dengan terganggunya kebisingan maka konsentrasi maka para pekerja dlam melakakukan pekerjaan akan banyak timbul kesalahan ataupun kerusakan sehingga akan menimbulkan kerugian bagi perushaan tersebut. Didalam suatu kantor, laboratorium, perpustakaan, batas kebisingan yang diperbolehkan adalah 40 dB.Di dalam pelaksanaan proses produksi dari suatu perusahaan, maka pada umumnya akan terdapat suara bising dari mesin dan peralatan produksi yang digunakan di dalam perusahaan yang bersangkutan. Suara bising yang terus-menerus sebenarnya akan dapat menurunkan kesehatan para karyawan yang bekerja di dalam perusahaan yang bersangkutan. Oleh karena itu penanggulangan terhadap suara bising ini sangat perlu untuk dipertimbangkan oleh manajemen perusahaan yang bersangkutan di dalam perencanaan kondisi kerja untuk para karyawan perusahaan pada khususnya, serta perencanaan lingkungan kerja pada umumnya.

Adapun beberapa metode yang dapat digunakan untuk pengaturan dan pengendalian suara bising yang terdapat di dalam perusahaan tersebut antara lain :

a. Pengendalian sumber suara

Pengurangan suara dari mesin dan peralatan produksi yang ada dan dipergunakan di dalam perusahaan yang bersangkutan akan dapat dilaksanakan dengan jalan mengadakan pemeliharaan yang baik dan teratur terhadap mesin dan peralatan tersebut. Selain itu, pengawasan terhadap bekerjanya pipa gas buang dari mesin-mesin perusahaan sangat diperlukan pula.

\section{b. Isolasi dari suara}

Di dalam beberapa hal, suara bising yang ditimbulkan oleh mesin dan peralatan yang digunakan tersebut dapat diisolir di dalam ruang mesin yang bersangkutan. Isolasi suara ini dapat dilaksanakan dengan menutup rapat ruang mesin tersebut dengan dinding tembok yang cukup kuat dan rapat, sehingga suara yang ditimbulkan oleh mesin yang bekerja di dalam ruang tersebut dapat diisolasi dengan baik. Dengan tertutup rapatnya ruangan tersebut, maka tidak boleh dilupakan untuk memberikan saluran gas buang yang cukup baik bekerjanya, keluar dari ruangan mesin tersebut dikarenakan penumpukan gas buang pada ruang mesin tersebut sangat membahayakan karyawan yang bekerja di dalam ruang tersebut. 


\section{c. Penggunaan peredam suara}

Peredam suara yang dipasang di dalam ruang kerja para karyawan (terutama pada karyawan bagian administrasi) ini akan menyerap getaran suara dan tidak memantulkannya. Peredam suara ini pada umumnya yang digunakan adalah karpet diamana akan dipasang pada setiap dinding ruangan tersebut akan dapat teredam dengan baik dan tidak dipantulkannya kembali oleh dinding-dinding ruang kerja tersebut.

\section{d. Penggunaan sistem akustik}

Dengan pemasangan sistem akustik ini, maka akan terdapat perubahan-perubahan kecil dari perencanaan ruang dilihat dari kepentingan mesin dan peralatan produksi yang digunakan. Hal ini disebabkan karena susunan ruangan yang akan dibuat dalam hal ini ditambah denganpertimbangan minimisasi dampak suara yang ditimbulkan oleh mesin dan peralatan yang digunakan di dalam perusahaan.

\section{e. Pemakaian alat perlindungan telinga}

Di dalam sebuah perusahaan terutama yang menggunakan alat-alat berat, akan terdapat beberapa ruangan tertentu yang mau tidak mau akan terdapat suara bising di dalam ruang tersebut. Untuk menghindarkan diri dari dampak negatif yang akan diderita oleh para karyawan yang bekerja di ruang tersebut, maka pada umumnya para karyawan yang bersangkutan akan dilengkapi dengan alat perlindungan telinga seperti air plug yang harus digunakan apabila para karyawan masuk ke dalam ruangan tersebut.

\section{Motion(Gerakan)}

Menurut Newstrom (1996:469-478)" kondisi gerakan secara umum adalah getaran". Getaran-getaran dapat menyebabkan pengaruh yang buruk bagi kinerja, terutama untuk aktivitas yang melibatkan penggunaan mata, gerakan tangan secara terus-menerus,serta pusing pada bagian kepala agar para karyawan perusahaan ini dapat leluasa bekerja dengan baik, maka ruang gerak dari para karyawan perlu diberikan di dalam besar ruangan yang memadai. Pada umumnya di dalam suatu perusahaan tersebut tidak diinginkan adanya penurunan produktifitas kerja yang dikarenakan oleh terlalu sempitnya ruang gerak para karyawan atau juga terjadinya pemborosan ruangan di dalam perusahaan tersebut.

Untuk menyusun ruang gerak yang tepat bagi para karyawan perusahaan tersebut, berikut disajikan gambar-gambar yang diperkirakan dapat membantu di dalam penyusunan ruang gerak tersebut. Bagan 42 dan 43 berikut ini dapat digunakan sebagai bahan pertimbangan di dalam penyusunan ruang gerak para karyawan.

\section{E. Pollution(Polusi)}

Menurut Newstrom (1996:469-478)," pencemaran ini dapat disebabkan karena tingkat pemakaian bahan-bahan kimia di tempat kerja dan keaneksragaman zat yang dipakai pada berbagai bagian yang ada di tempat kerja dan pekerjaan yang menghasilkan perabot atau perkakas". Bahan baku-bahan baku bangunan yang digunakan di beberapa kantor dapat dipastikan mengandung bahan kimia yang beracun. Situasi tersebut akan sangat berbahaya bagi para pekerja jika di tempat tersebut tidak terdapat ventilasi/saluran udara yang memadai. Maka dari itu perushaan yang bersangkutan wajib mempunyai sistem limbah yang baik agar pencemaran limbah tau polusi tidak berdampak bagi para karyawan yang dapat merugikan perusahaan.

\section{F. Aesthetic Factors(Faktor estetika)}

Menurut newstrom (1996:469-478)" faktor keindahan ini meliputi: musik, warna dan bau-bauan. Musik, warna dan bau-bauan yang menyenangkan dapat meningkatkan kepuasan kerja dalam melaksankan pekerjaanya".Oleh karena itu maka sebaiknya perusahaan memberikan warna yang cerah, musik yang sesuai pekerjaan, dan bau-bauan aroma wangi. 
Masalah penggunaan warna di dalam ruang kerja para karyawan perusahaan pada umumnya belum mendapatkan perhatian dengan semestinya oleh manajemen perusahaan yang bersangkutan. Pemilihan warna yang cerah atau yang gelap belum tentu akan menaikkan atau menurunkan produktifitas kerja para karyawan perusahaan yang bersangkutan.

\section{Kondisi psikologis dari lingkungan kerja}

Rancangan fisik dan desain dari pekerjaan, sejumlah ruangan kerja yang tersedia dan jenis-jenis dari perlengkapan dapat mempengaruhi perilaku dan kualitas pekerja dalam menciptakan macam-macam kondisi psikologi.

a. Feeling of privacy

Menurut Newstrom (1996:478), "privasi dari pekerja dapat dirasakan dari desain ruang kerja. Ada ruang kerja yang didesain untuk seorang pekerja, adapula yang didesain untuk beberapa orang, sehingga penyelia untuk mengawasi interaksi antar karyawan". Maka sebaiknya perusahan mendesain ruang kerja karyawan sesuai dengan bidang jenis perkerjaannya.

\section{b. Sense of status and impotance}

Menurut Newstrom (1996: 478)," para karywan tingkat bawah senang dengan desain ruang yang terbuka karena memberi kesempatan kepada karyawan untuk berkomunikasi secara informal. Sebaliknya para manajer merasa tidak puas dengan desain ruang yang terbuka karena banyak gangguan suara dan privasi yang dimiliki terbatas". Maka sebaiknya ruangan karyawan dan petinggi perusahaan di sesuaikan atau dipisahkan agar tidak menimbulkan kerugian bagi karywan maupun persuhaan tersebut.

\section{Kondisi sementara dari lingkungan kerja}

Menurut Newstrom (1996:480), "The temporal condition-the time structure of the work day. Some of the more flexible work schedules have developed in an effort to give workers a greater sense of control over the planning and timing of their work days" Kondisi sementara meliputi stuktur waktu pada hari kerja. Mayoritas perushaan memberi pekerjaan untuk karyawan dengan jadwal 5-9 jam, dimana pekerja akan diberi waktu biasanya 1 jam-1,5jam untuk dapat istirahat atau makan siang.Faktor-faktor dari kondisi sementara meliputi:

a. Shift

Menurut Newstrom (1996:481)," dalam satu hari sistem kerja shift dapat dibagi menjadi 3 yaitu shift pagi, shift psore, dan shift malam”. Dan berdasarkan banyak penelitian bahwa shift malam dianggap banyak menimbulkan masalah seperti stres yang tinggi, ketidakpuasan kerja kinerja yang buruk, ritme tubuh yang terganggu, adaptasi yang lambat karena bekerja shift malam, pekerja sering banyak melakukan kesalahan selama kerja shift malam, menurunnya kualitas pekerja, sering sakit pada shift malam, oleh karena itu maka perusahaan harus menerapakan seperti lamanya shift malam dikurangi tanpa mengurangi kompensasi dan benefit karyawan maupun perusahaan, jumlah karyawan shift malam dikurangi, lamanya shift malam sebaiknya tidak melebihi 8jam kerja.

\section{b. Compressed work weeks}

Menurut Newstrom (1996:481),"mengurangi jumlah hari kerja dalam seminggu, tetapi menambah jumlah jam kerja perhari”. Mengurangi hari kerja dalam seminggu mempunyai dampak yang positif dari karyawan yaitu karyawan dapat berkumpul bersama keluarga, merefresingkan pikiran dengan cara berlibur maka esok hari kerja karyawan akan merasa segar kembali pada waktu bekerja karena masa liburnya lebih lama dan juga dapat mengurangi tingkat kejenuhan dan stress pada saat kerja di perusahaan tersebut.

c. Flextime 
Menurut Newstrom (1996:481)," adalah suatu jadwal kerja dimana karywan dapat memutuskan kapan mulai bekerja dan kapan mengakhiri pekerjaannya selama karywan dapat memenuhi jumlah jam kerja yang ditetapkan oleh badan usaha."

kondisi kerja yang ENASE (Efektif, Nyaman, Aman, Sehat, dan Efisien) bagi para karyawan yang bekerja di perusahaan tersebut dalam melakukan produksi adalah sebagai berikut:

\title{
EFEKTIF
}

Efektif adalah pencapaian tujuan secara tepat atau memilih tujuan-tujuan yang tepat dari serangkaian alternatif atau pilihan cara dan menentukan pilihan dari beberapa pilihan lainnya. Maka dari itu bagian dari manajemen perusahaan harus dapat memilih tujuan atau langkah-langkah yang tepat agar para karyawan merasa dimudahkan dalam memproduksi hasil dari perushaan tersebut.Berikut adalah cara-cara kerja yang efektif:

1. Jangan menunda-nunda pekerjaan

2. Buat susunan daftar/ shedule pekerjaan

3. Gunakan pengingat waktu

4. Perushaan wajib memantau absensi karyawan

5. Perusahaan meberi reward kepada karyawan

6. Perushaan menerapkan hukuman/punishment kepada karyawan

\section{NYAMAN}

Bekerja dalam kondisi nyaman merupakan impian bagi para karyawan karena bekerja dalam kondisi nyaman membuat para karyawan menjadi senang, tidak terkekan dalam bekerja dan dapat meningkatkan hasil produksi dari perusahaan tersebut.Menurut NurheningYuniarti (2014:255),"Kesehatan dan keselamatan kerja merupakan hal yang essensial dan harus mendapatkan perhatian khusus dalam dunia kerja. Seorang pekerja yang berada pada lingkungan yang aman dan memiliki kesehatan yang baik akan cenderung lebih produktif dan memberikan keuntunganjangka panjang bagi perusahaan”.

1. Desain ruangan tempat kerja dibuat seunik mungkin

2. Memanjakan karyawan

3. Pemilihan Seragam

4. Menciptakan suasana yang menyenangkan dalam kantor

5. Desediakan asuransi

6. Pembersihan sekala berkala

\begin{abstract}
AMAN
1. Gunakan Alat Pelindung Diri (APD)

2. Pemasangan Rambu

3. Training K3

4. Pengaman Perusahaan
\end{abstract}

Bekerja dalam kondisi aman adalah pekerja tidak terganggu atau merasa takut dalam memproduksi hasil dari perusahaan tersebut. Menurut NurheningYuniarti (2014:255),"Kesehatan dan keselamatan kerja merupakan hal yang essensial dan harus mendapatkan perhatian khusus dalam dunia kerja. Seorang pekerja yang berada pada lingkungan yang aman dan memiliki kesehatan yang baik akan cenderung lebih produktif dan memberikan keuntunganjangka panjang bagi perusahaan".

\section{SEHAT}

Bekerja dalam kondisi sehat adalah pekerja merasa pekerjaan tidak menganggu kondisi tubuh (sakit).Berikut cara agar karyawan tepat sehat dalam bekerja

1. Tidak memberikan pekerjaan berlebih pada karyawan

2. Jam Istirahat yang cukup 
3. Perusahaan fasilitas pendukung kesehatan

4. Mengadakan senam sehat

\section{EFISIEN}

Efisien adalah segala sesuatu yang dikerjakan dengan berdaya guna atau segala sesuatunya dapat siselesaikan dengan tepat, cepat, hemat, dan selamat.

1. Mengatur waktu meeting (rapat)

2. Perusahaan menerapkan disiplin dengan waktu kerja dan waktu istirahat

3. Terapkan jam pulang kerja yang sesuai

4. Perusahaan menerapkan 5 hari kerja

5. Promosikan kultur komunikasi terbuka

6. Implementasikan teknologi smart mobile

7. Konsultasikan standar ergonomis

8. Analisa proses karyawan

9. Aturlah target yang dapat dicapai

10. Membuat visi dan misi perusahaan

\section{METODE}

Permasalahan di desa Srikamulyan Kecamatan Tirtajaya Kabupaten Karawang masih kurang dalam pengetahuan pengembangan wirausaha dengan menerapkan budaya kerja sehat. Dengan kondisi sehat sehingga dapat mengembangkan wirausaha dengan konsisten dan peduli terhadap lingkungan. Maka dilakukakn tahap persiapan sebagai berikut :

1. Tahap Persiapan Tahap persiapan yang dilakukan meliputi :

a. Survey

b. Pemantapan dan penentuan lokasi dan sasaran Penyusunan bahan/materi sosialisasi, yang meliputi : makalah dan modul untuk kegiatan Pengabdian Pada Masyarakat dengan tema "Pemberdayaan masyarakat desa melalui pelatihan perawatan dan pengelolaan kendaraan bermotor roda dua"

2. Tahap Pelaksanaan

Pada tanggal 30 November 2019 pelaksanaan kegiatan sosialisasi ini dilakukan penyuluhan, dalam kegiatan ini dilakukan beberapa tahapan:

a. Penjelasan tentang kualitas pelayanan usaha bengkel sepeda motor.

b. Penjelasan tentang manajemen bisnis service sepeda motor, Pada tahap ini menitikberatkan pada memberikan pemahaman pengetahuan kepada masyarakat desa mulya sejati sebaiknya usha apa yang harus dibuka.

c. Penjelasan tentang pengenalan spare part dan pencegahan mogok pada sepeda motor, pada tahap ini menitikberatkan bagaimana caranya agar kita mendaptkan modal usaha.

d. Penjelasan tentng cara perawatan sepeda motor untuk menciptakn kondisi kerja efektif, efisien, aman dan nyaman.

3. Metode Pelatihan Untuk melaksanakan kegiatan tersebut digunakan beberapa metode pelatihan, yaitu :

a. Metode Ceramah Metode ceramah dipilih untuk memberikan penjelasan tentang Sosialisasi agar dapat meningkatkan jiwa berwirausaha yang peduli dengan keselamtan pada masyarakat Srikamulyan.

b. Metode Tanya Jawab Metode tanya jawab sangat penting bagi para peserta pelatihan, baik di saat menerima penjelasan tentang berwirausaha serta saat mempraktekkannya, Metode ini memungkinkan masyarakat desa Srikamulyan menggali pengetahuan sebanyak-banyaknya.

c. Metode Praktek Metode simulasi ini sangat penting diberikan kepada para peserta pelatihan untuk memberikan kesempatan mempraktekan materi sosialisasi yang 
diperoleh. Harapannya, peserta sosialisasi akan benar-benar menguasai materi sosialisasi yang diterima, mengetahui tingkat kemampuannya menerapkan kegiatan berwirausaha secara teknis dan kemudian mengidentifikasi kesulitan kesulitan (jika masih ada) untuk kemudian dipecahkan.

\section{HASIL DAN PEMBAHASAN}

Kegiatan pelatihan perawatan dan pengelolaan kendaraan bermotor roda dua di desa Srikamulyan Kecamatan Tirtajaya Kabupaten Karawang dilaksanakan pada 30 November 2019. Kegiatan pelatihan berjalan dengan lancar yang diikuti oleh 30 peserta. Kegiatan diawali dengan penyuluhan dan dilanjutkan dengn praktik. Semua peserta mengikuti pelatihan dengan baik dan lancer terlihat antusiasme tinggi pada peserta pada saat pelatihan. Berdasarkan hasil kegiatan peserta pada saat mempraktikan melakukan perbaikan kendaraan bermotor roda dua yang sudah paham dan mengetahui cara perbaikan dan menyiapkan kondisi kerja dilihat dari kendaraan yang digunakan untuk praktik dapat berfungsi dengan baik, area kerja yang sehat tidak terjadi kecelakaan kerja dan tercipta nyaman,aman, efektif dan efisien.

\section{SIMPULAN}

Menerapkan kondisi kerja yang efektif efisien dan nyaman di lingkungan tempat kerja dapat diambil kesimpulan bahwa kondisi kerja adalah suatu kondisi kerja yang disiapkan pendiri usaha tersebut agar merasa nyaman,aman, efektif dan efisien. Kondisi kerja mempunyai beberapa faktor diantaranya:

1. Kondisi dari fisik dilingkungan kerja yang meliputi: Illumination(Penerangan), Temperature(Suhu), Noise(Kebisingan), Motion(Gerakan), Pollution(Polusi), dan Aesthetic Factors(Faktor estetika)

2. Kondisi psikologis dari lingkungan yang mempunyai beberapa faktor diantraranya : Sense of status and impotance, Feeling of privacy

3. Kondisi sementara dari lingkungan kerja yang meliputi: Compressed work weeks, Shift, Flextime

Perancangan sistem kerja yang bersifat ENASE (Efektif, Nyaman, Aman, Sehat, dan Efisien) bisa membuat pekerjaan yang sukar atau sulit menjadi sebuah pekerjaan yang mudah dan cepat dilaksanakan karena telah memiliki sebuah perencanaan yang baik. Maksud dari perancangan sistem kerja yang ENASE adalah diharapkan sistem atau kondisi kerja yang dirancang efektif yakni mampu menghasilkan output sesuai dengan tujuan yang ditetapkan, nyaman, aman, dan sehat bagi pekerja dan orang-orang yang berada di sekitar lingkungan tempat kerja itu berlangsung, serta efisien dalam arti bahwa biaya yang diperlukan untuk menyelesaikan suatu pekerjaan tertentu kecil nilainyau dibanding dengan output yang dihasilkan.

\section{DAFTAR PUSTAKA}

Ardis Bany Sutrisno ,artikel K3 "Menerapkan Kondisi Kerja Yang Efektif Efisien Dan Nyaman Di Lingkungan Tempat Kerja “, 2016, Yogyakarta.

DrsMoh. As'ad, S.U., Psi, psikologi industri "sumber daya manusia“, 1999, Liberty, Yogyakarta.

Tarwaka, PGDip.Sc., M.Erg.2014. Ergonomi Industri : Dasar-Dasar Ergonomi dan Implementasi di Tempat Kerja. Surkarta: Harapan Press Surakarta

Karlen, Mark. 2007. Dasar-dasar perancangan tempat kerja. Jakarta:Erlangga

Nurhening Yuniarti. 2014. Urgensi Pendidikan Kesehatan dan Keselamatan Kerja (K3) pada Pendidikan Kejuruan. Yogyakarta: STTN Batan.

W.Newstrom, John.1993. Organizational Behavior: Human Behavior at Work. USA: McGrawHill Education 